\section{Does engaging in corporate social responsibility activities influence firm performance? The moderating effects of risk preferences and performance measurement systems}

Performance measurement systems

\author{
Joanna Ho
}

Accounting, University of California Irvine, Irvine, California, USA

Cody Lu

Accounting, University of Massachusetts Amherst, Amherst, Massachusetts, USA, and

Lorenzo Lucianetti

Management Accounting, University of Chieti and Pescara, Pescara, Italy
Received 23 July 2020 Revised 1 December 2020 27 December 2020 Accepted 13 January 2021

\section{Abstract}

Purpose - This paper aims to examine whether and how two firm-level factors jointly moderate the relation between corporate social responsibility (CSR) activities and firm performance: (1) the "alignment" between a firm's CSR activities and risk preferences and (2) performance measurement systems (PMS).

Design/methodology/approach - Using survey responses from top managers of private Italian companies and matching archival data on the financial performance of these companies, the authors show that the positive effect of CSR activities on firm performance is contingent upon CSR-risk alignment, which creates competitive advantages, and the extent to which the firm's PMS are supportive of its strategic initiatives.

Findings - The findings suggest that to extract economic benefits from CSR activities, firms must align CSR activities with their risk preferences and rely on PMS to overcome the causal ambiguity between CSR activities and competitive advantage.

Originality/value - Overall, this study contributes to both the CSR-firm performance and consequences of PMS literature and holds significant practical implications.

Keywords Corporate social responsibility, Risk preferences, Alignment, Performance measurement systems Paper type Research paper

\section{Introduction}

Corporate social responsibility (CSR) has received significant attention in the business media (e.g. KPMG, 2015) and academic literature (Huang and Watson, 2015; Moser and Martin, 2012). Companies engage in CSR activities from an altruistic and economic perspective (e.g. Fernández-Kranz and Santaló, 2010; Hawn and Ioannou, 2016), which has sparked a growing interest in the use of CSR as a mechanism to attain competitive advantage (Filatotchev and Nakajima, 2014; Dupire and M'Zali, 2018). However, prior studies report

C Joanna Ho, Cody Lu and Lorenzo Lucianetti. Published by Emerald Publishing Limited. This article is published under the Creative Commons Attribution (CC BY 4.0) licence. Anyone may reproduce, distribute, translate and create derivative works of this article (for both commercial and non-commercial purposes), subject to full attribution to the original publication and authors. The full terms of this licence may be seen at http://creativecommons.org/licences/by/4.0/legalcode

Data Availability: Data used in this study are available upon request 
$\mathrm{MD}$

59,13

mixed findings on the relation between CSR activities and firm performance (Awaysheh et al., 2020; Broadstock et al., 2019; Griffin and Mahon, 1997; Margolis and Walsh, 2003; McWilliams and Siegel, 2001). For example, early studies have shown the relationship between CSR and firm performance to be positive (Waddock and Graves, 1997), negative (Wright and Ferris, 1997) or insignificant (McWilliams and Siegel, 2000). One explanation for this mixed evidence is a lack of understanding of the contingent factors that moderate the CSR-performance relation (McWilliams and Siegel, 2001; Servaes and Tamayo, 2013; Zhao and Murrell, 2016). As such, more recent studies have largely focused on identifying firmspecific variables that moderate this association (e.g. Farooq et al., 2017; Petrenko et al., 2016; Servaes and Tamayo, 2013; Surroca et al., 2010; Tang et al., 2012; Yuan et al., 2020), albeit taken together, the existing evidence still has not yielded a strong consensus as to the directional relationship between CSR and firm performance. The purpose of this study is to examine how the firm's risk preferences and performance measurement systems (PMS), two important and widely applicable factors to most organizations, jointly moderate the relationship between CSR and firm performance.

Although prior research has linked CSR to firm risk (Albuquerque et al., 2019; Dunbar et al., 2020; Godfrey, 2005), these studies have mainly focused on documenting how aggregate CSR affects a firm's risk-taking capacity, which in turn influences the firm's market valuation. We provide a different perspective by examining how different types of CSR activities interact with a firm's risk preferences to influence the firm's financial performance. Prior literature classifies CSR activities into two broad categories, external and internal. Tang et al. (2012) define external CSR activities as those that involve external stakeholders, such as charitable contributions, community service and environmental performance, and internal CSR activities as those that involve internal stakeholders, such as inclusion and non-discrimination policies, occupational health and safety and personnel benefits and training. As such, external CSR activities tend to be more publicly recognized, whereas internal CSR activities tend to be more internally appreciated (Farooq et al., 2017). The strategy literature finds that firms' risk preferences influence their decision-making, such that risk-seeking firms are more likely than risk-averse firms to embrace more aggressive approaches to distinguish themselves from the competition and achieve superior financial performance, e.g. strong emphasis on radical innovation, high propensity for risky investments (Bromiley and Rau, 2010; March, 1991; Mishina et al., 2004; Vanacker et al., 2017). We argue that because external CSR activities attract greater attention from external stakeholders and boosts public visibility (which may generate more opportunities for growth), engaging in greater external CSR activities will be relatively more (less) aligned with the overall attitude of risk-seeking (risk-averse) firms. On the other hand, as internal CSR activities typically appeal more to internal stakeholders (e.g. employees), which corresponds more closely to a "growth-from-within" approach, we posit that engaging in greater internal CSR activities will be relatively more (less) aligned with the overall philosophy of risk-averse (risk-seeking) firms. Thus, we define a firm as having achieved "CSR-risk alignment" if the firm is risk-seeking (risk-averse) and emphasizes external (internal) CSR activities to a greater extent than internal (external) CSR activities.

Furthermore, we investigate the role of PMS in the relationship between CSR activities, risk preferences and firm performance. PMS, such as the balanced scorecard, provide organizations with the necessary tools and techniques to direct activity and behavior toward the desired direction as a means of achieving strategic goals (Asiaei and Bontis, 2019; FrancoSantos et al., 2012; Kaplan and Norton, 1996; Lucianetti et al., 2019; Nguyen et al., 2017). According to Hall (2008), PMS represent a process that "translates business strategies into deliverable results" (p. 43). For instance, Nguyen et al. (2017) and Asiaei and Bontis (2019) show that PMS can be used to convert knowledge and leadership style into enhanced performance outcomes. Thus, given the importance of PMS for strategy implementation (Guth and Macmillan, 1986; Hall, 2008; Lucianetti et al., 2019), we argue that the effect of CSR- 
risk alignment on firm performance depends on the effectiveness with which PMS enable and facilitate CSR activities to synergize with risk preferences, thus creating competitive advantages for the firm.

To test our prediction, we surveyed top executives (e.g. chief executive officers (CEOs), chief finance officers (CFOs)) and controllers/managers (e.g. managing directors, operations managers) of Italian companies, both publicly listed and privately owned, to obtain data on their firms' CSR-related activities and risk-taking philosophy. More importantly, we acquire information on correspondents' perceptions of their firm's PMS. We then merged the responses for each firm with financial variables from the Aida-Bureau van Dijk database that contains financial information on firms operating in Italy. Using this combined dataset, we examine the relation between our measures of interest and several indicators of financial performance.

We find a significant moderation effect of PMS on the relation between CSR-risk alignment and firm performance. In other words, firms that engage in CSR activities aligned with their core risk-taking philosophy and employ effective PMS to capitalize on this alignment achieve higher economic returns. This suggests that CSR activities may not necessarily afford firms competitive advantages if these activities are not appropriately calibrated and supported with PMS. Our findings are robust to the presence of a multitude of control variables.

Our study contributes to the extant literature in three ways. First, we reconcile past studies on the CSR-performance relation by showing that risk preferences and PMS may partially explain the mixed findings on the association between CSR and firm performance. Specifically, while some firms effectively leverage PMS to create synergies between CSR activities and their core risk preferences, resulting in competitive advantage and superior firm performance, others may fail to do so. Thus, we document two important factors, representing features common to most organizations, that moderates the CSR-performance relation, which answers a call for research made in prior literature (Awaysheh et al., 2020; Broadstock et al., 2019; Griffin and Mahon, 1997; Margolis and Walsh, 2003; McWilliams and Siegel, 2001).

Second, CSR studies have largely treated CSR as an aggregate construct. However, recent papers have started to advocate for the disaggregation of CSR activities into different types (Farooq et al., 2017; Tang et al., 2012; Wang et al., 2016). In response to this call, we distinguish between external and internal CSR activities and show that engagement in these two types of CSR activities does not affect all companies equally. Rather, the effect depends on the extent to which CSR activities are aligned with a company's risk preferences and whether the company can successfully enable such activities, via PMS, to maximize the competitive advantages provided by this alignment.

Third, we provide important insights to managers and other stakeholders by substantiating the need to align CSR with their overall strategic risk-taking approach to achieve superior firm performance and documenting one mechanism (i.e. PMS) that can facilitate this process. This suggests that from an economic perspective, firms ought to selectively engage in CSR such that the chosen initiatives are aligned with their risk preferences (and, at a broader level, their strategic vision), which can be realized and supported using PMS. As such, given the increased interest and relevance of CSR to corporations and the business media alike (e.g. KPMG, 2015), our findings hold significant practical implications. More importantly, we believe that the recommendations derived from our study are highly applicable and generalizable in practice, given that most organizations employ PMS as an integral part of their management control system.

\section{Background and hypothesis development}

\subsection{Corporate social responsibility activities and firm performance}

CSR is broadly defined as the range of obligations that businesses have to society, including economic, ethical, legal and philanthropic (Aguinis and Glavas, 2012; Carroll, 1979, 1999;

Performance measurement systems 
$\mathrm{MD}$

59,13

Matten et al., 2003; Matten and Moon, 2020; McWilliams and Siegel, 2001). Furthermore, CSR activities can be classified into two broad categories, external and internal, which span several topical areas such as consumerism, discrimination, environment, occupational and product safety and shareholders (Tang et al., 2012). The distinction between external and internal CSR activities depends on whether the activity relates to external or internal stakeholders (Farooq et al., 2017), such that external (internal) CSR activities tend to be more publicly (internally) recognized. For instance, external CSR activities may involve charitable contributions, community service and environmental performance. By contrast, internal CSR activities may involve inclusion and non-discrimination policies, occupational health and safety and personnel benefits and training (Tang et al., 2012).

Many studies have documented the relation between CSR activities and firm performance in the management literature, with early evidence suggesting mixed results (Griffin and Mahon, 1997; Margolis and Walsh, 2003; McWilliams and Siegel, 2001). For example, Waddock and Graves (1997) find that corporate social performance (CSP) is positively associated with future firm performance. By contrast, Wright and Ferris (1997) document a significantly negative association between CSP and firm performance. McWilliams and Siegel (2000) argue that prior inconsistencies in the literature may be due to model misspecification issues. Similarly, in a more recent study, Zhao and Murrell (2016) replicate Waddock and Graves (1997) using a larger and longer sample and fail to find a significantly positive relationship between CSP and firm performance. As a result, the authors conclude that the original findings may not generalize to alternate samples.

As a result of the early mixed evidence on the CSR-performance relation, recent studies in the CSR literature have devoted significant attention to providing a better understanding of factors that moderate the CSR-performance relation. For instance, Surroca et al. (2010) find that CSR activities stimulate the development of intangible resources, leading to improved financial performance. Tang et al. (2012) document that the manner in which firms engage in CSR (e.g. consistently, focusing on related dimensions and beginning with the internal dimensions) strengthens the positive CSR-performance relationship. Servaes and Tamayo (2013) show that the association between CSR and firm value is dependent on customer awareness, as proxied by advertising expenditures. Lys et al. (2015) demonstrate that rather than affecting earnings performance, CSR activities serve as a signal of future performance, which drives their documented positive relation. Awaysheh et al. (2020) find that relative benchmarking of CSR performance to industry peers serves as an important contingent factor to the positive CSR-performance relation. At a more conceptual level, numerous studies have demonstrated the "value-added" of selectively engaging in CSR that synthesizes and is compatible with the organization's core strategic initiatives, which serves as a catalyst for competitive advantage (e.g. Cheng et al., 2015; Porter and Kramer, 2006; Yuan et al., 2020). However, not all studies document a positive moderation effect on the CSR-performance relation. Relying on upper echelons and agency theories, Petrenko et al. (2016) find that the benefits of CSR activities cannot justify their costs, which leads to adverse consequences on firm performance. The authors show that CSR activities are a function of a narcissistic CEO's personal desire for attention and reputation, and thus, CEO narcissism reduces the effect of CSR activities on performance. Indeed, Al-Shammari et al. (2019) corroborate this explanation by documenting a significantly positive (insignificant) association between CEO narcissism and emphasis on external (internal) CSR activities.

Notwithstanding the insights provided by these studies, there remains a lack of consensus on the circumstances and situations in which CSR benefits or hurts firm performance. One reason for this may be because prior studies have largely disregarded the importance of distinguishing between external and internal CSR activities and their unique impact on firm performance (Al-Shammari et al., 2019; Porcena et al., 2020; Tang et al., 2012). In this paper, we attempt to further broaden the extant knowledge in this area by explicitly 
examining whether and how CSR activity type (external versus internal) depends on and interacts with the firms' risk preferences and PMS to influence their competitive advantages and performance.
Performance measurement systems

\subsection{Hypothesis development}

The resource-based view of the firm suggests that firms represent bundles of resources, which tend to be static over time (Amit and Schoemaker, 1993; Barney, 2001; Bag et al., 2019; Boyd et al., 2009; Kunc and Morecroft, 2010; Peteraf, 1993; Sirmon et al., 2007; Wernerfelt, 1984). Firms may possess resources that are valuable, rare, inimitable and non-substitutable and can be utilized to gain competitive advantages (Barney, 1991, 2001; Boyd et al., 2009). Sirmon et al. (2007) propose the resource management model as a theoretical framework linking resource management to value creation. The main components of this framework center around the notion that firms can structure their bundles of resources to build organizational capabilities and, in turn, leverage these capabilities to gain competitive advantages. Relatedly, resource complementarity refers to the influence that different organizational resources have on each other, and how the interactive relationships between resources affect the organization's overall competitive position and performance (Amit and Schoemaker, 1993; Black and Boal, 1994; Boyd et al., 2009; Dierickx and Cool, 1989; Kunc and Morecroft, 2010; Mishra et al., 2019; Wernerfelt, 1984). Resources can have one of three effects on other resources: enhancing, suppressing or compensating (Black and Boal, 1994). An enhancing (suppressing) effect exists when changes in the level of one resource increase (decrease) the impact of another. By contrast, a compensating effect exists when changes in the level of one resource cancel out the impact of another.

Drawing on the notion of resource complementarity, we examine how engaging in CSR interacts with a firm's risk preferences and PMS to influence firm performance [1]. In our setting, CSR and PMS represent two types of resources available to the firm. While it can be argued that neither alone represents a rare or "superior" resource per se (Barney, 1991, 2001; Peteraf, 1993; Wernerfelt, 1984), we expect that the combination of the two, along with the firm's risk preferences, may serve to create unique competitive advantages for the firm. We define CSR-risk alignment as whether a firm's CSR activities are consistent or congruent with its core risk-taking philosophy. Specifically, we propose that this depends on the type of CSR activity that the firm engages in (external vs internal) and the firm's risk preference (riskseeking vs risk-averse).

Based on existing evidence in the strategy literature (e.g. Bromiley and Rau, 2010; March, 1991; Mishina et al., 2004; Vanacker et al., 2017), a firm's risk preference dictates the manner in which it utilizes slack resources to achieve competitive advantage. Given resource constraints, risk-seeking firms are more likely to allocate such resources to radical innovation and high-risk investments to expand a firm's market or product position. By contrast, risk-averse firms are more likely to allocate such resources to maximize internal growth and development to improve operational efficiency (Bromiley and Rau, 2010; March, 1991; Mishina et al., 2004).

To expand the market or product position, risk-seeking firms are greatly reliant on the perceptions and support of external stakeholders. The burden is on the firms to convince external stakeholders of the quality and reliability of their radical innovations and risky investments. One way to accomplish this is to increase the firm's (positive) public visibility, which reduces any information asymmetry between external stakeholders and the firm (Mishra, 2017). This, in turn, would increase the likelihood that external stakeholders will support the firm. Thus, in light of resource constraints, risk-seeking firms should engage in greater external CSR initiatives, which are more publicly visible, to attract external stakeholders' attention and enhance the firm's competitive advantage. Therefore, we argue 
$\mathrm{MD}$

59,13

that a risk-seeking firm achieves CSR-risk alignment by allocating more slack resources toward engaging in external, as opposed to internal, CSR activities.

On the other hand, risk-averse firms are relatively more inclined to focus on employee relations to improve workers' loyalty, satisfaction and retention to achieve competitive advantage [2]. For instance, investing in employee training and internal career development and providing good retirement benefits can help employees stay motivated and induce them to stay with the firm (Rajagopalan, 1997). This, in turn, would lead to greater development of personnel and increased downstream performance benefits, which ultimately improves the firm's operational efficiency. Furthermore, to avoid potential disruption to operations, it is imperative for risk-averse firms to maintain good relations with labor unions. Thus, in light of resource constraints, risk-averse firms should engage in greater internal CSR initiatives, which tend to be more internally recognized and appreciated, to enhance the morale and commitment of employees (and other internal personnel) and increase the firm's competitive advantage. Therefore, we argue that a risk-averse firm achieves CSR-risk alignment by allocating more slack resources toward engaging in internal, as opposed to external, CSR activities.

However, we do not expect a significant relationship between CSR-risk alignment and firm performance, unless the firm possesses a strong infrastructure for strategy implementation. Thus, we predict that PMS will enhance the impact of CSR-risk alignment on firm performance. We rely on Hall's (2008) definition of PMS as a tool used by firms to "translate business strategies into deliverable results" (p. 43). Contemporary PMS, such as the balanced scorecard, play a vital role in facilitating business strategy by providing a "blueprint" for strategy implementation (Asiaei and Bontis, 2019; Chenhall and LangfieldSmith, 1998; Franco-Santos et al., 2012; Guth and Macmillan, 1986; Kaplan and Norton, 1996; Lucianetti et al., 2019; Nguyen et al., 2017). For instance, PMS can be used to communicate and review strategic goals and initiatives within an organization (Henri, 2006a, b). Also, PMS improve strategy implementation efforts by enhancing managers' strategic judgments (Cheng and Humphreys, 2012), reinforcing managers' goal commitment (Webb, 2004) and reducing the influence of motivated reasoning (i.e. bias) on managers' strategy evaluation (Tayler, 2010). In a comprehensive review of the literature, Franco-Santos et al. (2012) find that these factors collectively have a positive effect on organizational capabilities and subsequent performance. Nguyen et al. (2017) show that PMS mediate the influence of transformational leadership style on managerial performance, while Asiaei and Bontis (2019) report that PMS play a significant role in translating knowledge resources and process capabilities into enhanced performance. Taken together, there is abundant evidence to suggest that PMS are instrumental in strategy reinforcement and implementation.

Based on this discussion, we expect CSR-risk alignment to have a significantly positive effect on firm performance only when a firm's PMS are designed in a manner that more effectively facilitates its strategic initiatives. In other words, PMS will maximize the unique competitive advantage created by aligning CSR activities with the firm's risk preferences, leading to superior performance. Therefore, we conjecture that CSR-risk alignment will interact with PMS to influence firm performance. Figure 1 presents a visual depiction of our conceptual model. Our hypothesis is formally stated as follows:

HO. There is a positive relationship between CSR activities and financial performance when the firm achieves CSR-risk alignment, and PMS effectively facilitate strategic initiatives.

\section{Method}

\subsection{Data}

Our sample population consisted of Italian companies listed on the Aida-Bureau van Dijk database, which contains up to ten years of accounting and corporate finance data of public 
and private firms operating in Italy, as well as multinational corporations filing separately for their Italian operations. Aida-Bureau van Dijk is a major publisher of business information that specializes in private company data. The database combines information from regulatory and other sources, including 160 information providers, with software that allows users to analyze the data for various research needs and applications. Unlike other data providers, Aida-Bureau van Dijk discloses the original source(s) of their data, which affords users the ability to create their own analytics based on their assessment of the reliability of the underlying data sources. Accordingly, we form our initial sample of potential respondents based on Italian companies on Aida-Bureau van Dijk. We selected a wide range of organizations, spanning different industry sectors and organizational characteristics, to maximize our sample's representativeness and increase the generalizability of our results.

To test our hypotheses, we distributed a survey questionnaire via email to each of these companies to gather necessary information related to their CSR activities, risk-taking philosophy, PMS and other relevant variables used in our analyses. Survey scales and items were adapted from previously validated scales. However, as prior research has typically not focused on Italian firms, we further modified the scales (where necessary) to ensure that they are applicable to and compatible with our sample. We utilize a survey approach to gather data because many of the pertinent variables in our study, such as risk-taking philosophy and PMS, are not publicly available or disclosed. Our research design minimizes the potential influence of common method bias on our results, given that we employ multiple sources (i.e. both an archival database and a survey) to gather data for our dependent and independent variables of interest. First, we contacted each firm's management directly by phone to select a list of companies willing to cooperate with our research. Then, we identified and targeted high-level executives (e.g. CEOs, CFOs) as well as controllers and managers (e.g. managing directors, operations managers) to complete the questionnaire, as the positional levels of these individuals increases the likelihood that our respondents possess substantive and specific knowledge about their firm's PMS. Names and email addresses of our potential respondents were obtained during phone conversations. We followed up with respondents every two months after distributing the initial survey questionnaire, for a total of three times, to increase our response rate.

The questionnaire was created, managed and submitted to managers using Qualtrics (https://www.qualtrics.com), a Web-based tool to conduct survey research, evaluations and other data collection activities. It was preceded by an introductory letter clarifying the purposes and objectives of the research project. Managers were also promised an overall PMS benchmark allowing them to compare their responses to those of other participating organizations. To operationalize our constructs, we sought to identify existing scales that can be employed or scales that can be adapted to the specific context. We carefully pre-tested the initial survey questionnaire to assure that respondents could correctly understand the questions. First, we discussed a preliminary draft of the questionnaire with academic scholars to assess clarity, simplicity and content validity. Afterward, a pilot study was conducted with six accounting managers and controllers from four large organizations. Their
Performance measurement systems

Conceptual Framework

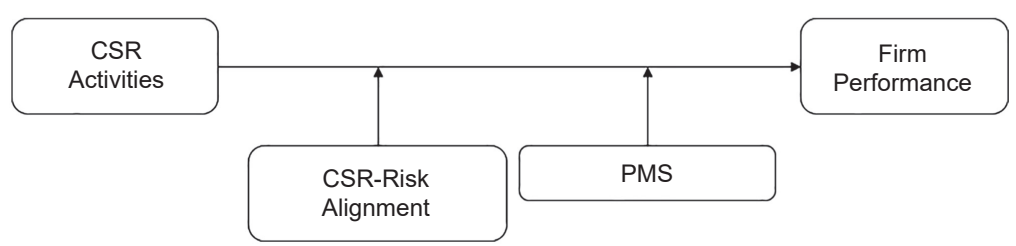

Figure 1. 
$\mathrm{MD}$

59,13

\section{2}

inputs were used to improve the clarity, comprehensiveness and relevance of the survey questions. Finally, the revised survey was reviewed by a panel of three academics.

Of the 1,334 companies that were surveyed, 264 responses from 229 unique firms were collected, yielding a response rate of about 17\% [3]. Table 1 presents demographic information on our survey respondents. Over $80 \%$ of our respondents are male and have at least a bachelor's degree. While $64 \%$ of our respondents are over the age of $40,82 \%$ of them have been in their current positions for three years or less, suggesting that top managers in our sample have relatively short tenures.

Table A1 presents survey items used in this study, associated summary statistics and indicators of discriminant and convergent validity. We test for discriminant validity by comparing the squared correlation between every pair of constructs and the respective average variance extracted for each construct. Discriminant validity is present if the AVE of a given construct is higher than the squared correlation between that construct and all other constructs (Fornell and Larcker, 1981). Our untabulated results show none of the squared correlations is higher than each respective construct's AVE, indicating adequate discriminant validity of our survey items. Composite reliabilities and Cronbach's alphas for each of our constructs are greater than 0.8 , which exceeds the threshold of 0.7 commonly used in social sciences research (Nunnally 1978), suggesting sufficient convergent validity and scale reliability of our survey items.

We test for the presence of non-response bias in two ways (untabulated). First, we compare two firm-level variables, size (i.e. total assets) and industry classification (i.e. manufacturing

\begin{tabular}{lccc}
\hline & Frequency & $\%$ & Cumulative \% \\
\hline Gender & & & \\
Male & 234 & 0.886 & 0.886 \\
Female & 30 & 0.114 & 1.000 \\
Education & & & \\
High school & 43 & 0.163 & 0.163 \\
Bachelor & 153 & 0.580 & 0.742 \\
Postgraduate & 68 & 0.258 & 1.000 \\
Age & & & \\
$\leq 30$ & 12 & 0.045 & 0.045 \\
$31-40$ & 75 & 0.284 & 0.330 \\
$41-50$ & 107 & 0.405 & 0.735 \\
$51-60$ & 55 & 0.208 & 0.943 \\
$61-70$ & 7 & 0.027 & 0.970 \\
Missing & 8 & 0.030 & 1.000 \\
Experience (years) & & & \\
1 & 109 & 0.413 & 0.413 \\
2 & 71 & 0.269 & 0.682 \\
3 & 37 & 0.140 & 0.822 \\
4 & 7 & 0.027 & 0.848 \\
5 & 7 & 0.027 & 0.875 \\
6 & 3 & 0.011 & 0.886 \\
7 & 5 & 0.019 & 0.905 \\
8 & 8 & 0.030 & 0.936 \\
9 & 9 & 0.030 & 0.966 \\
Missing & 9 & 0.034 & 1.000 \\
Note(s): Gender is measured as a binary variable. Education & is & \\
experience are measured as continuous variables & & \\
& & &
\end{tabular}

Table 1.

Respondents' demographics

\section{experience are measured as continuous variables}


versus service), between firms that did and did not respond to our survey. We fail to find statistically significant differences for these two variables between our two groups. This suggests that our sample firms are similar in size and industry composition to that of the target population. Thus, we believe that non-response bias is unlikely to be a significant confounding factor in explaining our results [4]. Second, we compare demographic characteristics between early and late respondents (Moore and Tarnai, 2002), where early (late) respondents are defined as those with survey completion dates, recorded by Qualtrics, belonging in the initial (latter) third of our sample. We fail to find statistically significant differences for gender, age and job experience between the two groups, and only a marginal difference for education ( $10 \%$ significance level).

\subsection{Measures}

3.2.1 Dependent variables. We use two accounting-based performance measures as our dependent variables: return on assets (ROA) and return on sales (ROS). Because we ask respondents (at one point in time) to rate their company's performance on CSR indicators relative to the industry average over the past two years, we compute the average of ROA and ROS over the two years before administering our survey to cleanly capture the influence of firms' CSR activities on financial performance and facilitate interpretation of our results [5].

3.2.2 Corporate social responsibility. We measure the extent to which firms engage in CSR using an instrument containing seven items that asks respondents to rate their firm's performance along several dimensions of discretionary citizenship on a six-point Likert-type scale (adapted from Maignan and Ferrell, 2000). Two (five) of the items relate to internal (external) CSR activities that are associated with employee welfare (charity, environment, community and product). Our classifications are consistent with the definitions in prior literature for external and internal CSR (e.g. Farooq et al., 2017; McWilliams and Siegel, 2001; Tang et al., 2012). We generate variables for the extent of firms' overall (CSR), external (CSR_EXT) and internal (CSR_INT) CSR activities by taking an equal-weighted average of the responses on the individual items. Higher values indicate greater engagement in CSR [6].

3.2.3 Risk preferences. To operationalize firm risk preferences, we ask respondents to rate the extent to which their organizations' philosophy emphasizes strategic risk-taking, using a six-item instrument on a six-point Likert-type scale that we developed and validated. We chose to develop our own risk-taking measure instead of relying on more established ones in the literature to better cater our survey items to our institutional context. While the Italian economy has a history of innovation and risk-taking, the current economy has become highly bureaucratic and risk-averse. For instance, Malanima and Zamagni (2010) argue that as the global economy has become more entrepreneurial, Italy has regressed in terms of the country's overall entrepreneurial spirit. Thus, we design our own measure of strategic risktaking to best capture the firms' risk preferences in our sample.

To develop our measure, we outline several key features that constitute strategic risktaking. At a conceptual level, risk-taking behavior involves the willingness to commit more firm resources to endeavors that could generate large returns even if the cost of failure is high (Miller and Friesen, 1982). Additionally, lower risk preferences are often associated with more internally focused processes, such as cost minimization strategies and greater internal financing. By contrast, high-risk preferences are often associated with more externally focused processes, such as technological leadership and greater external financing (Porter, 1980). Therefore, risk-seeking firms will engage in more strategic risk-taking behavior centered around innovativeness and proactiveness to gain first-mover advantages. On the other hand, risk-averse firms will engage in more strategic risk-taking behavior emphasizing optimal internal processes and systems, which involve less uncertainty and are more predictably managed. Based on these characteristics, we derive our six-item strategic risk-
Performance measurement systems 
$\mathrm{MD}$

59,13

taking measure to capture firm risk preferences [7]. Based on this approach, we believe that our decision to develop a new scale to capture our construct of interest is appropriate, as we are able to incorporate context-specific factors into our measure of firms' risk preferences in a systematic manner.

We employ principal component analysis (PCA), with oblimin rotation, to extract common factors and find that our analysis yields two separate components with an eigenvalue greater than one [8]. Upon further examination, the significant factor loadings on the first component relate to risk-taking associated with the investment and mobilization of resources, whereas those of the second component captures risk-taking associated with competition (e.g. through investment, financing and operations management). Given the distinction between different types of risk-taking activities (e.g. Damanpour 1991; Lewis et al. 2002), we argue that the second component will be a less noisy (i.e. cleaner) proxy for a firm's overall risk preferences, given that the second component entails risk-taking activities that relate to gaining an advantage over competitors, and outperforming the competition is generally the overarching objective of all firms. Therefore, we believe that the second component is a more representative measure of our construct of interest. We compute our measure of risk preferences, RISK, as an indicator variable that equals 1 (risk-seeking) if the second component of our strategic risk-taking measure for a given firm is greater than that of the sample median [9], and 0 (risk-averse) otherwise [10].

3.2.4 Corporate social responsibility-risk alignment. We define CSR-risk alignment (ALIGN) as an indicator variable that equals 1 if risk-seeking (risk-averse) firms engage in higher (lower) levels of external relative to internal CSR activities, and 0 otherwise. In other words, ALIGN equals 1 when firms are classified as a risk-seeking (risk-averse) and score higher (lower) on the average of the external CSR survey items than the internal CSR survey items. In our context, ALIGN captures whether the nature of a firm's CSR activities matches its core risk-taking philosophy.

3.2.5 Performance management systems. We ask respondents to rate the extent to which various strategic reasons for using PMS are important to their firm, based on a six-point Likert-type scale. The question contains nine items related to strategy communication and review adapted from Kaplan and Norton's (1996) seminal work on the balanced scorecard and its influence on strategy review and communication, which we posit will enhance the effect of the alignment between CSR activities and risk preferences on firm performance[11]. A PCA of the nine items yields two components with an eigenvalue greater than one. After using the oblimin rotation, we observe that the significant factor loadings on the first (second) component are more closely associated with the communication (review) of strategic initiatives. Therefore, we label the first and second components as REASON_COM and REASON_REV, respectively.

3.2.6 Control variables. Following prior literature (Barnett and Salomon, 2012; Servaes and Tamayo, 2013; Waddock and Graves, 1997), we include several control variables that may affect our hypothesized relation in our model. For example, PMS maturity (MATURITY) and the number of employees (EMPLOYEE) capture the length of PMS use and level of human capital, respectively, and are measured on seven-point Likert scales. Industrial patents and intellectual property rights (IPIPR) proxy for intangible assets, while plant and machinery (PM) and industrial and commercial equipment (ICE) control for tangible assets, where all three variables are scaled by total assets and averaged over the two years prior to the survey end date[12]. MULTI is an indicator variable that equals 1 if the firm is part of a multinational entity, and 0 otherwise, which accounts for the effects of cultural/regional attributes on PMS' determinants and consequences. INDUSTRY captures industry effects and equals $1(0)$ if the firm is in the manufacturing (service) industry. Additionally, we control for total assets (SIZE), measured as the natural logarithm of total assets (averaged over the two years prior to the survey end date). Both leverage (LEV) and 
accounting return volatility (ACTVOL) proxy for firm risk. LEV is measured as total debts divided by total assets, also averaged over the two years prior, and ACTVOL is the standard deviation of ROA over the previous five years. Definitions of every variable used in our study can be found in Table A2.
Performance measurement systems

\subsection{Model specifications}

We employ the following ordinary least squares (OLS) model, with variables as previously defined, to test our hypothesis:

$$
\begin{aligned}
\text { FINPERF }_{i}= & \beta_{0}+\beta_{1} \mathrm{CSR}_{i}+\beta_{2} \mathrm{RISK}_{i}+\beta_{3} \mathrm{ALIGN}_{i}+\beta_{4} \mathrm{REASON}_{i}+\beta_{5} \mathrm{ALIGN}_{i} * \mathrm{REASON}_{i} \\
& +\sum_{6}^{15} \beta_{i} \operatorname{Control}_{i}+\epsilon_{i}
\end{aligned}
$$

FINPERF corresponds to the measures of financial performance, while REASON corresponds to either REASON_COM or REASON_REV. As discussed earlier, we expect a positive coefficient on $\beta_{5}$, which is the interaction that captures the moderating effect of PMS on the relationship between CSR-risk alignment and financial performance.

\section{Results}

\subsection{Descriptive statistics}

To conduct our analyses, we exclude firms without financial variables data on the AidaBureau van Dijk database and/or those with missing values for our key financial performance variables (i.e. ROA and ROS). Our final sample includes 144 companies [13]. Table 2 presents summary statistics of the variables included in our main analyses [14]. Column (1) shows the average rating of CSR is 3.801, suggesting that respondents believed their firms performed better than the industry average on select CSR activities. CSR_INT (3.872) is slightly higher

\begin{tabular}{|c|c|c|c|c|c|c|c|}
\hline \multirow[b]{2}{*}{ Variable } & \multicolumn{2}{|c|}{ Full sample (1) } & \multicolumn{2}{|c|}{$\begin{array}{l}\text { Risk-seeking } \\
\text { firms (2) }\end{array}$} & \multicolumn{2}{|c|}{$\begin{array}{c}\text { Risk-averse firms } \\
\text { (3) }\end{array}$} & \multirow{2}{*}{$\begin{array}{c}\text { Difference (4) } \\
(2)-(3)\end{array}$} \\
\hline & Mean & STD & Mean & STD & Mean & STD & \\
\hline CSR & 3.801 & 1.069 & 4.066 & 1.007 & 3.536 & 1.070 & $0.530 * * *$ \\
\hline CSR_EXT & 3.772 & 1.109 & 4.051 & 1.020 & 3.494 & 1.131 & $0.558^{* * * *}$ \\
\hline CSR_INT & 3.872 & 1.187 & 4.102 & 1.156 & 3.642 & 1.180 & $0.459 * *$ \\
\hline ALIGN & 0.410 & 0.493 & 0.347 & 0.479 & 0.472 & 0.503 & $-0.125^{*}$ \\
\hline ROA & 0.058 & 0.063 & 0.051 & 0.057 & 0.066 & 0.069 & -0.015 \\
\hline ROS & 0.061 & 0.069 & 0.055 & 0.072 & 0.066 & 0.066 & -0.011 \\
\hline MATURITY & 4.507 & 1.797 & 4.625 & 1.533 & 4.389 & 2.032 & 0.236 \\
\hline MULTI & 0.583 & 0.495 & 0.528 & 0.503 & 0.639 & 0.484 & -0.111 \\
\hline EMPLOYEE & 2.722 & 1.934 & 2.611 & 1.961 & 2.833 & 1.914 & -0.222 \\
\hline IPIPR & 0.006 & 0.034 & 0.002 & 0.006 & 0.010 & 0.047 & -0.008 \\
\hline PM & 0.065 & 0.098 & 0.056 & 0.078 & 0.072 & 0.114 & -0.016 \\
\hline ICE & 0.010 & 0.023 & 0.013 & 0.029 & 0.008 & 0.014 & 0.005 \\
\hline SIZE & 11.656 & 1.854 & 11.597 & 2.155 & 11.715 & 1.508 & -0.118 \\
\hline LEV & 0.138 & 0.163 & 0.141 & 0.163 & 0.134 & 0.164 & 0.006 \\
\hline ACTVOL & 0.041 & 0.051 & 0.046 & 0.054 & 0.037 & 0.049 & 0.009 \\
\hline INDUSTRY & 0.646 & 0.480 & 0.597 & 0.494 & 0.694 & 0.464 & -0.097 \\
\hline
\end{tabular}
than CSR_EXT (3.772) on average; however, the difference is statistically insignificant [15].

Note(s): * ** and *** denote significance at the 10,5 and $1 \%$ levels, respectively. All variables are as defined in Table A2

Table 2.

Descriptive statistics 
$\mathrm{MD}$

59,13

\section{6}

In addition, $41 \%$ of the firms achieve CSR-risk alignment. Columns (2) and (3) present the summary statistics by risk preference, as well as differences in the variables between firms that are risk-seeking and risk-averse in column (4). On average, risk-seeking firms score higher on external, internal and overall CSR performance than risk-averse firms. On the other hand, a greater percentage of risk-averse firms achieve CSR-risk alignment. Means for all other variables are statistically indistinguishable between the two groups at conventional levels.

Table 3 presents the Pearson correlation matrix of the variables used in our main analyses. As expected, the correlations among our PMS measures are significant at the $1 \%$ level, which suggests that each variable adequately proxies for the intended construct of interest. In addition, PMS measures (i.e. REASON_COM and REASON_REV) are significantly correlated with CSR measures and RISK, suggesting an interaction between firms' PMS and their CSR activities and risk preference. However, it is ultimately an empirical question as to whether any such interactive effects influence firm performance, which we turn to next.

\subsection{Hypothesis tests}

We standardize all non-indicator explanatory variables to facilitate interpretation of the results and use one-tailed $p$-values to test our coefficient of interest $\left(\beta_{5}\right)$. Table 4 summarizes the regression results and shows significant and positive coefficients on ALIGN $\times$ REASON_COM (REASON_REV) in the first (latter) two columns. This indicates that, ceteris paribus, firms can improve financial performance by ensuring an alignment between their CSR activities and risk preferences and using PMS to maximize the competitive benefits of this alignment.

Although unrelated to our formal hypothesis, we find that the coefficients on ALIGN are not significant in any column, suggesting that simply aligning CSR activities with risk preferences alone is insufficient for firms to improve their financial performance [16]. This is consistent with our overall theoretical argument that PMS help firms harness this alignment by overcoming the causal ambiguity that exists between CSR activities and competitive advantage. However, we acknowledge that a lack of statistical power, given our relatively small sample size, may have contributed to these insignificant findings. Nonetheless, our analysis yields strong support for our hypothesis.

As shown in Table 2, Panel B, the mean of CSR_INT is significantly higher than that of CSR_EXT for both risk-seeking and risk-averse firms. There is also a greater percentage of firms that achieve CSR-risk alignment in the risk-averse group than in the risk-seeking group. Thus, it may be the case that risk-averse firms and/or firms with more internal CSR activities are driving our results. As such, we partition our sample based on risk-seeking versus risk-averse firms, as well as firms with higher versus lower scores on CSR_INT and re-run the regressions in Table 4 under both scenarios (untabulated). We find no discernible differences in our main findings in either case, reducing the likelihood that risk-averse firms or firms with more internal CSR activities are driving our results.

\subsection{Supplemental interview analyses}

To assess the validity of our survey instruments and substantiate that they accurately measure the intended constructs of interest, we conducted subsequent interviews with top managers at 36 of our sample firms. We are particularly interested in examining the extent to which our survey questions appropriately capture our CSR measures. We selected 18 risk-seeking and risk-averse firms each, which were meant to represent our sample firms based on the characteristics such as firm size and industry, to form our interview sample. We then contacted respondents at these firms by email and phone to request an interview and informed them that the interview would take approximately $10 \mathrm{~min}$ of their time. 


\begin{tabular}{|c|c|c|c|c|c|c|}
\hline & (1) & (2) & (3) & (4) & (5) & (6) \\
\hline (1) ROA & 1.000 & & & & & \\
\hline (2) ROS & $0.741^{* * * *}$ & 1.000 & & & & \\
\hline (3) CSR & 0.126 & 0.082 & 1.000 & & & \\
\hline (4) CSR_EXT & 0.103 & 0.077 & $0.977 * * *$ & 1.000 & & \\
\hline (5) CSR_INT & $0.155^{*}$ & 0.076 & $0.870 * * *$ & $0.745 * * *$ & 1.000 & \\
\hline (6) RISK & -0.118 & -0.079 & $0.249 * * *$ & $0.252^{* * *}$ & $0.194^{* * *}$ & 1.000 \\
\hline (7) ALIGN & 0.043 & 0.027 & -0.095 & -0.102 & -0.062 & -0.127 \\
\hline (8) REASON_COM & $0.186^{* *}$ & 0.129 & $0.465^{* * *}$ & $0.438 * * *$ & $0.444^{* * *}$ & $0.272^{* * *}$ \\
\hline (9) REASON_REV & 0.089 & 0.072 & $0.517 * * * *$ & $0.454^{* * *}$ & $0.568^{* * * *}$ & $0.258^{* * * *}$ \\
\hline (10) MATURITY & 0.040 & -0.003 & $0.149^{*}$ & 0.135 & $0.153^{*}$ & 0.066 \\
\hline (11) MULTI & $0.167 * *$ & $0.167^{* *}$ & 0.021 & -0.001 & 0.066 & -0.113 \\
\hline (12) EMPLOYEE & 0.005 & 0.125 & $0.166^{* *}$ & $0.161^{*}$ & $0.149^{*}$ & -0.058 \\
\hline (13) IPIPR & -0.039 & -0.042 & $-0.149 *$ & -0.141 & $-0.144^{*}$ & -0.111 \\
\hline (14) PM & 0.016 & -0.002 & 0.111 & 0.127 & 0.054 & -0.081 \\
\hline (15) ICE & -0.002 & -0.045 & -0.019 & -0.025 & -0.001 & 0.104 \\
\hline (16) SIZE & -0.134 & 0.056 & 0.074 & 0.101 & -0.002 & -0.032 \\
\hline (17) LEV & $-0.199 * *$ & -0.104 & $-0.194^{* *}$ & $-0.173^{* *}$ & $-0.208^{* *}$ & 0.020 \\
\hline (18) ACTVOL & -0.033 & -0.104 & $0.159 *$ & $0.156^{*}$ & $0.139 *$ & 0.088 \\
\hline \multirow[t]{2}{*}{ (19) INDUSTRY } & 0.005 & 0.001 & -0.009 & 0.039 & -0.120 & -0.102 \\
\hline & (7) & (8) & (9) & (10) & (11) & (12) \\
\hline (7) ALIGN & 1.000 & & & & & \\
\hline (8) REASON_COM & 0.060 & 1.000 & & & & \\
\hline (9) REASON_REV & 0.076 & $0.622 * * *$ & 1.000 & & & \\
\hline (10) MATURITY & -0.007 & $0.281^{* * *}$ & $0.215^{* * * *}$ & 1.000 & & \\
\hline (11) MULTI & -0.012 & 0.033 & -0.021 & 0.124 & 1.000 & \\
\hline (12) EMPLOYEE & -0.012 & 0.022 & 0.119 & 0.039 & $0.302^{* * *}$ & 1.000 \\
\hline (13) IPIPR & 0.107 & -0.102 & -0.117 & 0.043 & 0.052 & 0.046 \\
\hline (14) PM & -0.023 & 0.026 & -0.066 & 0.105 & 0.022 & 0.139 \\
\hline (15) ICE & -0.030 & -0.037 & 0.000 & -0.127 & -0.062 & 0.036 \\
\hline (16) SIZE & -0.076 & -0.080 & 0.054 & $0.155^{*}$ & $0.208^{* *}$ & $0.445^{* * * *}$ \\
\hline (17) LEV & -0.008 & $-0.100 *$ & -0.124 & -0.087 & $-0.276 * * *$ & $-0.140^{*}$ \\
\hline (18) ACTVOL & -0.056 & 0.062 & 0.067 & $0.159 *$ & $0.159 *$ & -0.091 \\
\hline \multirow[t]{2}{*}{ (19) INDUSTRY } & -0.121 & -0.028 & -0.046 & 0.099 & $0.140^{*}$ & 0.021 \\
\hline & (13) & (14) & (15) & (16) & (17) & (18) \\
\hline (13) IPIPR & 1.000 & & & & & \\
\hline (14) PM & -0.001 & 1.000 & & & & \\
\hline (15) ICE & -0.057 & 0.010 & 1.000 & & & \\
\hline (16) SIZE & $0.164^{*}$ & 0.101 & -0.090 & 1.000 & & \\
\hline (17) LEV & $0.193^{* *}$ & 0.007 & 0.016 & 0.081 & 1.000 & \\
\hline (18) ACTVOL & -0.002 & $0.261^{* * *}$ & -0.057 & -0.003 & -0.033 & 1.000 \\
\hline (19) INDUSTRY & -0.110 & 0.003 & $0.199 * *$ & $0.194^{* * *}$ & 0.012 & $-0.180^{* * *}$ \\
\hline
\end{tabular}

Note(s): $* * *$ and $* * *$ denote significance at the 10,5 and $1 \%$ levels, respectively. All variables are as defined in Table A2

Table 3.

Pearson correlations

All respondents that were initially contacted agreed to participate, at which time we scheduled the interviews. The final interviews were conducted over the phone.

We asked these managers to elicit their agreement with whether the following items correspond to external CSR activities: "reducing the amount of waste in energy and materials" (item 4), “improving sustainability through product design" (item 6) and 
MD

59,13

28

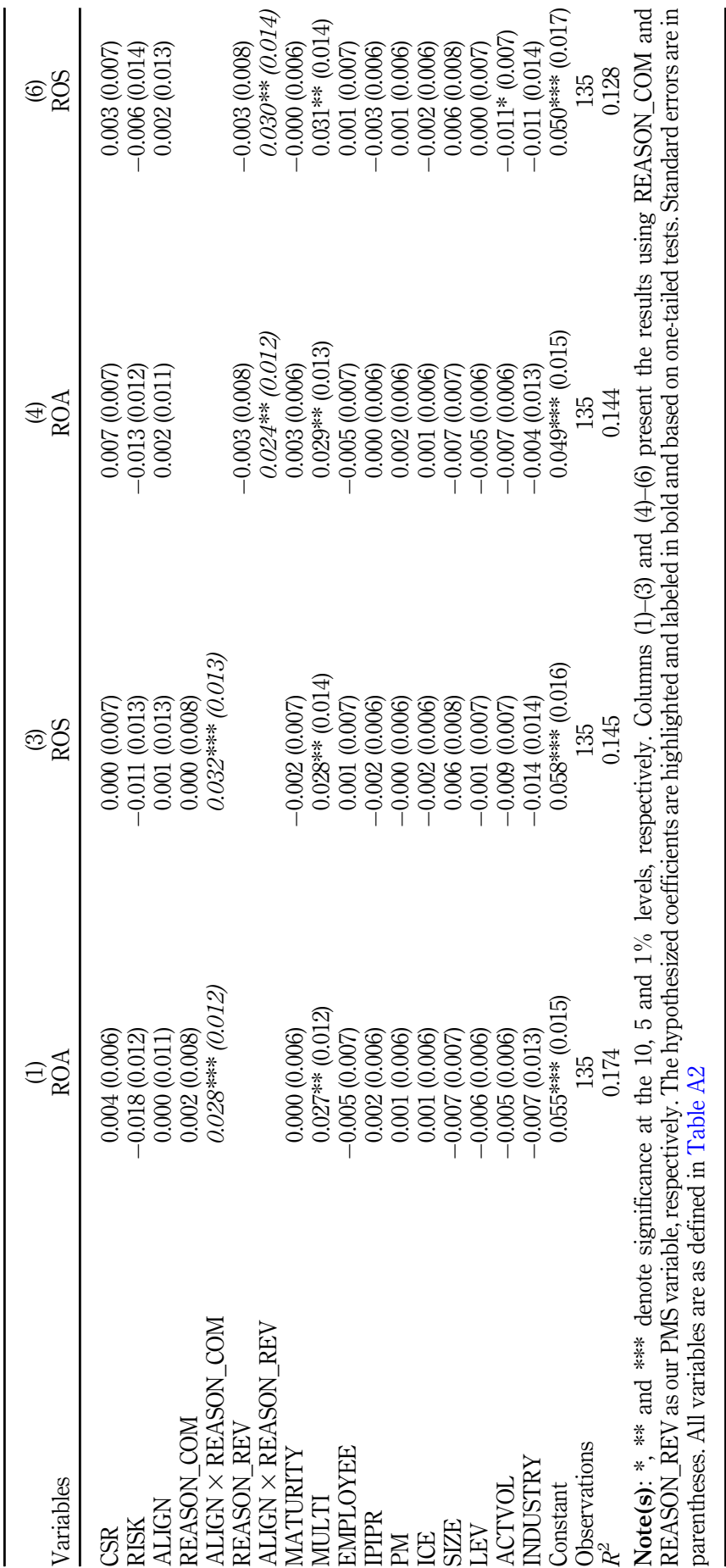

Table 4.

The moderating effect of PMS on CSR-risk alignment and financial performance 
"improving sustainability via product return policies/processes" (item 7). We chose these items due to the potential ambiguity associated with their CSR classification. The extent of agreement was captured on a seven-point scale, where 1 (7) represents strongly disagree (agree), with a midpoint of 4 representing neither agree nor disagree. The interview results (untabulated) suggest that overall, respondents agreed that all three items capture external CSR activities, with means for each item (5.806, 5.694 and 5.778, respectively) that are significantly higher than the midpoint of $4(p<0.01)$, thus validating our CSR classifications. Overall, our interview results confirm the internal validity of our CSR measures.
Performance measurement systems

\section{Discussion}

In this study, we examine how risk preferences and PMS moderate the relation between CSR activities and firm performance through the perspective of resource complementarity. We predict and find that CSR activities positively affect firm performance when: (1) firms align the CSR activities that they choose to engage in with their core risk philosophy and (2) PMS are effective in facilitating and supporting this alignment. In other words, our results are consistent with the notion that PMS enhance the effect of CSR-risk alignment on firm performance.

Our study makes theoretical contributions to the CSR literature. First, we extend the growing body of work seeking to dispel the mixed findings associated with the relation between CSR and firm performance (Huang and Watson, 2015; Margolis and Walsh, 2003; Moser and Martin, 2012). Specifically, we show that whether firms achieve CSR-risk alignment and, more importantly, the extent to which firms' PMS help achieve this alignment by reducing the causal ambiguity between CSR activities and competitive advantage, can influence the effect of CSR on firm performance. Thus, we document two interrelated factors that moderate the CSR-performance relation, answering a call made in prior literature (Awaysheh et al., 2020; Broadstock et al., 2019).

Our study also emphasizes the distinction between external and internal CSR activities, which is important because recent papers have started to advocate for the disaggregation of CSR activities into different components (Farooq et al., 2017; Tang et al., 2012; Wang et al., 2016). We show that these two types of CSR activities have differential effects on firm performance based on the firm's risk preference and the effectiveness of the firm's PMS, which allows such activities to serve its intended purpose.

As there has been an increased propensity for firms to engage in CSR activities (KPMG, 2015), our findings hold important practical implications. Specifically, our results substantiate the importance of aligning CSR with risk preferences to achieve competitive advantages and superior firm performance, which are incremental to the altruistic benefits that can be derived from undertaking CSR activities. Furthermore, we document the PMS' enhancing role in accomplishing these goals by incorporating PMS as an additional moderator within the CSR-performance framework. Our findings reiterate the importance of effectively using PMS to promote communication and review of strategic goals and initiatives, a sentiment echoed in the extant literature (Guth and Macmillan, 1986; Hall, 2008; Lucianetti et al., 2019). Given high levels of strategy implementation failure rates (Candido and Santos, 2015), it is imperative to shed light on the "black box" through which corporate strategies translate into competitive advantages and economic returns, especially when strategies crucially depend on the effective configuration of valuable resources such as CSR activities, as we show in this study. Thus, from an economic perspective, our results imply that firms ought to selectively engage in CSR activities that align well with their strategic vision and to use PMS to facilitate and support this alignment. Given the widespread implementation of PMS and the vitally important function that they serve in a firm's management control system (Franco-Santos et al., 2012; Lucianetti et al., 2019), we believe that 
$\mathrm{MD}$

59,13

managers, board directors and other stakeholders will find the recommendations prescribed in our study to be highly applicable and generalizable in practice.

Notwithstanding these insights, our study is subject to several limitations. First, our research design is not exempt from the common limitations associated with using survey data, e.g. common method bias. However, given that we obtain measures of our dependent variables using a separate data source (i.e. an archival database), we do not expect these issues to significantly influence our results. Our sample size is also limited to only 144 firms, which reduces statistical power (relative to larger samples). However, we expect that this lack of power will likely bias against finding results and thus, cause our documented effects to be understated. Additionally, we cannot validate the robustness of our findings using CSR data from external sources (e.g. Asset4) due to data availability constraints. Finally, our study is conducted using firms operating in Italy and thus, may not generalize to other cultural/national contexts. However, to the extent that our theory is applicable to different types of organizations in general, we expect our findings to hold practical value and significance.

We believe additional research is necessary to supplement our findings. For instance, future research can examine alternative channels through which PMS can potentially moderate the relation between CSR-risk alignment and firm performance, such as middle manager commitment (Guth and Macmillan, 1986), administrative mechanisms (Govindarajan, 1988), market orientation (Dobni and Luffman, 2003) and external relationships (Mahama, 2006). It may be the case that these factors have a similar, or even incremental, effect relative to strategy implementation in creating competitive advantages and value for the firm via engagement in CSR activities. Future research may also find it fruitful to explore the impact of emerging technologies on the effectiveness and scope of PMS in facilitating competitive advantages related to CSR activities and other types of resources, given the disruptive nature of technology in organizations. For instance, data analytics may further exacerbate the impact and value of PMS to organizations that we observe by increasing the efficiency and quality of users' judgments and decision-making. Our study provides the groundwork to pursue these intriguing areas of research.

\section{Notes}

1. Prior studies examining the relation between CSR and firm risk have mostly focused on showing how aggregate CSR directly affects a firm's risk-taking capacity, which in turn influences the firm's market valuation (Albuquerque et al., 2019; Dunbar et al., 2020; Godfrey, 2005).

2. This is not to say that focusing on public visibility has no benefits for risk-averse firms; rather, we argue that taking actions (involving costly resources) that cater to internal stakeholders is more congruent with the goals and preferences of risk-averse firms.

3. There are more responses than firms because we elicit responses from more than one individual in each firm to increase the total number of unique firms (and hence, the response rate) in our sample. To deal with the multiple-response issue, we average the responses across all the participants for a given firm.

4. We cannot obtain demographic characteristics for non-respondents; thus, we use late respondents as a proxy for non-respondents (Moore and Tarnai, 2002). Our untabulated results show that respondents are similar to late respondents demographically.

5. In untabulated tests, we also average our performance measures over the three and five years before administering our survey and find qualitatively similar results.

6. We are unable to use external sources (e.g. Asset4, CSR reports, CDP surveys) to measure the CSR activities of our sample firms due to a lack of data on private companies, which comprise $90.4 \%$ of our sample. We do not expect issues generalizing our findings to Italian firms overall because as of August 2020, only 457 companies were publicly listed on the Italian Stock Exchange. This 
comprises less than $1 \%$ of all firms in Italy; therefore, we believe that our sample is representative of Italian firms.

7. The six items are: "strong emphasis on research and development," "technological leadership and innovations," "strong proclivity to high-risk, high-return investments," "growth strategy primarily through external financing (borrowings, capital issues, etc.)," "very competitive, "undo-thecompetitors' philosophy," "mobilizing tangible resources to achieve goals" and "mobilizing intangible resources to pursue goals."

8. We use oblimin rotation because our factors are not completely orthogonal from each other (i.e. there is overlap among them), which is a key assumption for using varimax rotation. Our untabulated results show qualitatively similar results when we employ varimax rotations.

9. We partition at the median instead of at more extreme deciles to preserve statistical power due to sample size limitations.

10. We recognize the possibility that using a survey question to proxy for firms' risk preferences may capture what firms claim their attitude toward risk is as opposed to what it actually is, e.g. based on observable actions. However, our sample contains very few publicly listed companies, which drastically limits our ability to employ market-based proxies of risk preferences.

11. The nine items are: "check that business strategy is being implemented," "manage strategy implementation," "plan strategic actions of the business," "communicate strategy to employees," "communicate strategy to external stakeholders," "communicate direction," "establish and communicate business position," "review business strategy" and "challenge assumptions in strategy." For a recent application of this scale, see Lucianetti et al. (2019).

12. We do not include research and development expenses to control for intangible assets due to concerns of "throwing the baby out with the bath water" as one item of our risk-taking philosophy measure explicitly asks respondents for the extent to which their company has a "strong emphasis on research and development, technological leadership, and innovations."

13. In the multivariate analyses, our sample size reduces to 135 observations due to missing values for control variables.

14. Latent constructs associated with our survey items are omitted from this table because PCA yields standardized variables. See Table A1 for summary statistics related to individual survey items.

15. This could be because there are only two items in the discretionary citizenship question associated with internal CSR activities as opposed to five items for that of external CSR activities. Thus, the computation of CSR_INT may be particularly sensitive to extreme values, which gives rise to the relationship we observe.

16. In our model, ALIGN serves only as a benchmark in that it represents the effect of CSR-risk alignment on firm performance for an average level of REASON (i.e. a mean of 0 ).

\section{References}

Aguinis, H. and Glavas, A. (2012), "What we know and don't know about corporate social responsibility: a review and research agenda", Journal of Management, Vol. 38 No. 4, pp. 932-968.

Al-Shammari, M., Rasheed, A. and Al-Shammari, H.A. (2019), "CEO narcissism and corporate social responsibility: does CEO narcissism affect CSR focus?”, Journal of Business Research, Vol. 104, pp. 106-117.

Albuquerque, R., Koskinen, Y. and Zhang, C. (2019), "Corporate social responsibility and firm risk: theory and empirical evidence", Management Science, Vol. 65 No. 10, pp. 4451-4469.

Amit, R. and Schoemaker, P.J.H. (1993), "Strategic assets and organizational rent", Strategic Management Journal, Vol. 14 No. 1, pp. 33-46.
Performance measurement systems 
$\mathrm{MD}$

59,13

Asiaei, K. and Bontis, N. (2019), "Translating knowledge management into performance: the role of performance measurement systems”, Management Research Review, Vol. 43 No. 1, pp. 113-132.

Awaysheh, A., Heron, R.A., Perry, T. and Wilson, J.I. (2020), "On the relation between corporate social responsibility and financial performance”, Strategic Management Journal, Vol. 41 No. 6, pp. 965-987.

Bag, S., Gupta, S. and Foropon, C. (2019), "Examining the role of dynamic remanufacturing capability on supply chain resilience in circular economy", Management Decision, Vol. 57 No. 4, pp. 863-885.

Barnett, M.L. and Salomon, R.M. (2012), "Does it pay to be really good? Addressing the Shape of the relationship between social and financial performance”, Strategic Management Journal, Vol. 33 No. 11, pp. 1304-1320.

Barney, J.B. (1991), "Firms resources and sustained competitive advantage", Journal of Management, Vol. 17 No. 1, pp. 99-120.

Barney, J.B. (2001), "Is the resource-based 'view' a useful perspective for strategic management research?”, Yes. Academy of Management Review, Vol. 26 No. 1, pp. 41-56.

Black, J.A. and Boal, K.B. (1994), "Strategic resources: traits, configurations and paths to sustainable competitive advantage", Strategic Management Journal, Vol. 15, pp. 131-148.

Boyd, B.K., Bergh, D.D. and Ketchen, D.J. (2009), "Reconsidering the reputation-performance relationship: a resource-based view", Journal of Management, Vol. 36 No. 3, pp. 588-609.

Broadstock, D.C., Managi, S., Matousek, R. and Tzeremes, N.G. (2019), "Does doing 'good' always translate into doing 'well'? An eco-efficiency perspective", Business Strategy and the Environment, Vol. 28 No. 6, pp. 1199-1217.

Bromiley, P. and Rau, D. (2010), "Risk taking and strategic decision making", in Nutt, P.C. and Wilson, D.C. (Eds), Handbook of Decision Making, Wiley, Chichester, pp. 307-326.

Candido, C.J.F. and Santos, S.P. (2015), "Strategy implementation: what is the failure rate?", Journal of Management and Organization, Vol. 21 No. 2, pp. 237-262.

Carroll, A.B. (1979), "A three-dimensional conceptual model of corporate performance”, Academy of Management Review, Vol. 4 No. 4, pp. 497-505.

Carroll, A.B. (1999), "Corporate social responsibility: evolution of a definitional construct", Business and Society, Vol. 38 No. 3, pp. 268-295.

Cheng, M.M. and Humphreys, K.A. (2012), "The differential improvement effects of the strategy map and scorecard perspectives on managers' strategic judgments", The Accounting Review, Vol. 87 No. 3, pp. 899-924.

Cheng, M.M., Green, W. and Ko, J. (2015), "The impact of strategic relevance and assurance of sustainability indicators on investors' decisions", Auditing: A Journal of Practice and Theory, Vol. 34 No. 1, pp. 131-162.

Chenhall, R.H. and Langfield-Smith, K. (1998), "Factors influencing the role of management accounting in the development of performance measures within organizational change programs", Management Accounting Research, Vol. 9 No. 4, pp. 361-386.

Damanpour, F. (1991), "Organizational innovation: a meta-analysis of effects of determinants and moderators", Academy of Management Journal, Vol. 34 No. 3, pp. 555-590.

Dierickx, I. and Cool, K. (1989), "Asset stock accumulation and sustainability of competitive advantage", Management Science, Vol. 35 No. 12, pp. 1504-1511.

Dobni, B.C. and Luffman, G. (2003), "Determining the scope and impact of market orientation profiles on strategy implementation and performance", Strategic Management Journal, Vol. 24 No. 6, pp. 577-585.

Dunbar, C., Li, Z. and Shi, Y. (2020), "CEO risk-taking incentives and corporate social responsibility", Journal of Corporate Finance, Vol. 64, pp. 1-21. 
Dupire, M. and M'Zali, B. (2018), "CSR strategies in response to competitive pressures", Journal of Business Ethics, Vol. 148 No. 3, pp. 603-623.

Farooq, O., Rupp, D.E. and Farooq, M. (2017), "The multiple pathways through which internaland external corporate social responsibility influence organizational identification and multifoci outcomes: the moderating role of cultural and social orientations", Academy of Management Journal, Vol. 60 No. 3, pp. 954-985.

Fernández-Kranz, D. and Santaló, J. (2010), "When necessity becomes a virtue: the effect of product market competition on corporate social responsibility", Journal of Economics and Management Strategy, Vol. 19 No. 2, pp. 453-487.

Filatotchev, I. and Nakajima, C. (2014), "Corporate governance, responsible managerial behavior, and corporate social responsibility: organizational efficiency versus organizational legitimacy?", Academy of Management Perspectives, Vol. 28 No. 3, pp. 289-306.

Fornell, C. and Larcker, D.F. (1981), "Evaluating structural equation models with unobservable variables and measurement error", Journal of Marketing Research, Vol. 18 No. 1, pp. 39-50.

Franco-Santos, M., Lucianetti, L. and Bourne, M. (2012), "Contemporary performance measurement systems: a review of their consequences and a framework for research", Management Accounting Research, Vol. 23 No. 2, pp. 79-119.

Godfrey, P.C. (2005), "The relationship between corporate philanthropy and shareholder wealth: a risk management perspective", Academy of Management Review, Vol. 30 No. 4, pp. 777-798.

Govindarajan, V. (1988), "A contingency approach to strategy implementation at the business- unit level: integrating administrative mechanisms with strategy", Academy of Management Journal, Vol. 31 No. 4, pp. 828-853.

Griffin, J.J. and Mahon, J.F. (1997), "The corporate social performance and corporate financial performance debate: twenty-five years of incomparable research", Business and Society, Vol. 36 No. 1, pp. 5-31.

Guth, W.D. and Macmillan, I.C. (1986), "Strategy implementation versus middle management selfinterest", Strategic Management Journal, Vol. 7 No. 4, pp. 313-327.

Hall, M. (2008), "The effect of comprehensive performance measurement systems on role clarity, psychological empowerment and managerial performance", Accounting, Organizations and Society, Vol. 33 Nos 2-3, pp. 141-163.

Hawn, O. and Ioannou, I. (2016), "Mind the gap: the interplay between external and internal actions in the case of corporate social responsibility", Strategic Management Journal, Vol. 37 No. 13, pp. 2569-2588.

Henri, J.F. (2006a), "Management control systems and strategy: a resource-based perspective", Accounting, Organizations and Society, Vol. 31 No. 6, pp. 529-558.

Henri, J.F. (2006b), "Organizational culture and performance measurement systems", Accounting, Organizations and Society, Vol. 31 No. 1, pp. 77-103.

Huang, X.B. and Watson, L. (2015), "Corporate social responsibility research in accounting”, Journal of Accounting Literature, Vol. 34, pp. 1-16.

Kaplan, R.S. and Norton, D.F. (1996), The Balanced Scorecard: Translating Strategy into Action, Harvard Business School Press, Boston, Massachusetts, MA.

KPMG (2015), "The KPMG survey of corporate responsibility reporting”, available at: www.kpmg. $\mathrm{com} /$ (accessed 11 November 2017).

Kunc, M.H. and Morecroft, J.D.W. (2010), "Managerial decision making and firm performance under a resource-based paradigm”, Strategic Management Journal, Vol. 31 No. 11, pp. 1164-1182.

Lewis, M.W., Welsh, M.A., Dehler, G.E. and Green, S.G. (2002), "Product development tensions: exploring contrasting styles of project management", Academy of Management Journal, Vol. 45 No. 3, pp. 546-564. 
$\mathrm{MD}$

59,13

Lucianetti, L., Battista, V. and Koufteros, X. (2019), "Comprehensive performance measurement systems design and organizational effectiveness", International Journal of Operations and Production Management, Vol. 39 No. 2, pp. 326-356.

Lys, T., Naughton, J.P. and Wang, C. (2015), "Signaling through corporate accountability reporting", Journal of Accounting and Economics, Vol. 60 No. 1, pp. 56-72.

Mahama, H. (2006), "Management control systems, cooperation and performance in strategic supply relationships: a survey in the mines", Management Accounting Research, Vol. 17 No. 3, pp. 315-339.

Maignan, I. and Ferrell, O.C. (2000), "Measuring corporate citizenship in two countries: the case of the USA and France", Journal of Business Ethics, Vol. 23 No. 3, pp. 283-297.

Malanima, P. and Zamagni, V. (2010), "150 years of the Italian economy, 1981-2010", Journal of Modern Italian Studies, Vol. 15 No. 1, pp. 1-20.

March, J.G. (1991), "Exploration and exploitation in organization learning", Organization Science, Vol. 2 No. 1, pp. 71-87.

Margolis, J.D. and Walsh, J.P. (2003), "Misery loves companies: rethinking social initiatives by business", Administrative Science Quarterly, Vol. 48, pp. 268-305.

Matten, D. and Moon, J. (2020), "Reflections on the 2018 decade award: the meaning and dynamics of corporate social responsibility", Academy of Management Review, Vol. 45 No. 1, pp. 7-28.

Matten, D., Crane, A. and Chapple, W. (2003), "Behind the mask: revealing the true face of corporate citizenship", Journal of Business Ethics, Vol. 45, pp. 109-120.

McWilliams, A. and Siegel, D.S. (2000), "Corporate social responsibility and financial performance: correlation or misspecification?”, Strategic Management Journal, Vol. 21 No. 5, pp. 603-609.

McWilliams, A. and Siegel, D.S. (2001), "Corporate social responsibility: a theory of the firm perspective", Academy of Management Review, Vol. 26 No. 1, pp. 117-127.

Miller, D. and Friesen, P.H. (1982), "Innovation in conservative and entrepreneurial firms: two models of strategic momentum”, Strategic Management Journal, Vol. 3 No. 1, pp. 1-25.

Mishina, Y., Pollock, T.G. and Porac, J.F. (2004), "Are more resources always better for growth? Resource stickiness in market and product expansion”, Strategic Management Journal, Vol. 25, pp. 1179-1197.

Mishra, D.R. (2017), "Post-innovation CSR performance and firm value", Journal of Business Ethics, Vol. 140, pp. 285-306.

Mishra, D., Luo, Z., Hazen, B., Hassini, E. and Foropon, C. (2019), "Organizational capabilities that enable big data and predictive analytics diffusion and organizational performance: a resourcebased perspective”, Management Decision, Vol. 57 No. 8, pp. 1734-1755.

Moore, D.L. and Tarnai, J. (2002), "Evaluating nonresponse error in mail surveys", in Groves, R.M., Dillman, D.A., Eltinge, J.L. and Little, R.J.A. (Eds), Survey Nonresponse, John Wiley \& Sons, New York, NY, pp. 197-211.

Moser, D.V. and Martin, P.R. (2012), “A broader perspective on corporate social responsibility research in accounting", The Accounting Review, Vol. 87 No. 3, pp. 797-806.

Nguyen, T.T., Mia, L., Winata, L. and Chong, V.K. (2017), "Effect of transformational-leadership style and management control system on managerial performance", Journal of Business Research, Vol. 70, pp. 202-213.

Nunnally, J.C. (1978), Psychometric Theory, McGraw-Hill, New York, NY.

Peteraf, M.A. (1993), "The cornerstones of competitive advantage: a resource-based view", Strategic Management Journal, Vol. 14 No. 3, pp. 179-191.

Petrenko, O.V., Aime, F., Ridge, J. and Hill, A. (2016), "Corporate social responsibility or CEO narcissism? CSR motivations and organizational performance", Strategic Management Journal, Vol. 37 No. 2, pp. 262-279. 
Porcena, Y.R., Parboteeah, K.P. and Mero, N.P. (2020), "Diversity and firm performance: role of corporate ethics", Management Decision, Vol. ahead-of-print No. ahead-of-print.

Porter, M.E. (1980), Competitive Strategy: Techniques for Analyzing Industries and Competitors, Free Press, New York, NY.

Porter, M.E. and Kramer, M.R. (2006), "Strategy and society", Harvard Business Review, Vol. 84, pp. 78-92.

Rajagopalan, N. (1997), "Strategic orientations, incentive plan adoptions and firm performance: evidence from electric utility firms", Strategic Management Journal, Vol. 18 No. 10, pp. 761-785.

Servaes, H. and Tamayo, A. (2013), "The impact of corporate social responsibility on firm value", Management Science, Vol. 59 No. 5, pp. 1045-1061.

Sirmon, D.G., Hitt, M.A. and Ireland, R.D. (2007), "Managing firm resources in dynamic environments to create value: looking inside the black box", Academy of Management Review, Vol. 32 No. 1, pp. 273-292.

Surroca, J., Tribo, J.A. and Waddock, S. (2010), "Corporate responsibility and financial performance: the role of intangible resources", Strategic Management Journal, Vol. 31, pp. 463-490.

Tang, Z., Hull, C.E. and Rothenberg, S. (2012), "How corporate social responsibility engagement strategy moderates the CSR-financial performance relationship", Journal of Management Studies, Vol. 49 No. 7, pp. 1274-1303.

Tayler, W.B. (2010), "The balanced scorecard as a strategy-evaluation tool: the effects of implementation involvement and a causal-chain focus", The Accounting Review, Vol. 85 No. 3, pp. 1095-1117.

Vanacker, T., Collewaert, V. and Zahra, S.A. (2017), "Slack resources, firm performance, and the institutional context: evidence from privately held European firms", Strategic Management Journal, Vol. 38 No. 6, pp. 1305-1326.

Waddock, S.A. and Graves, S.B. (1997), "The corporate social performance-financial performance link", Strategic Management Journal, Vol. 18 No. 4, pp. 303-319.

Wang, H., Tong, L., Takeuchi, R. and George, G. (2016), "Corporate social responsibility: an overview and new research directions: thematic issue on corporate social responsibility", Academy of Management Journal, Vol. 59 No. 2, pp. 534-544.

Webb, A.R. (2004), "Managers' commitment to the goals contained in a strategic performance measurement system", Contemporary Accounting Research, Vol. 21 No. 4, pp. 925-958.

Wernerfelt, B. (1984), “A resource-based view of the firm”, Strategic Management Journal, Vol. 5 No. 2 , pp. 171-180.

Wright, P. and Ferris, S.P. (1997), "Agency conflict and corporate strategy: the effect of divestment on corporate value”, Strategic Management Journal, Vol. 18 No. 1, pp. 77-83.

Yuan, Y., Lu, L.Y., Tian, G. and Yu, Y. (2020), "Business strategy and corporate social responsibility", Journal of Business Ethics, Vol. 162 No. 2, pp. 359-377.

Zhao, X. and Murrell, A.J. (2016), "Revisiting the corporate social performance-financial performance link: a replication of Waddock and Graves", Strategic Management Journal, Vol. 37 No. 11, pp. 2378-2388. 
MD

59,13

36

\section{Appendix A}

\begin{tabular}{lccccc}
\hline & Mean & STD & AVE & $\begin{array}{c}\text { Composite } \\
\text { reliability }\end{array}$ & $\begin{array}{c}\text { Cronbach's } \\
\text { alpha }\end{array}$ \\
\hline Purpose of PMS & & & 0.603 & 0.931 & 0.951
\end{tabular}

The reasons my company measure performance are to

Communicate strategy to employees 3.545

Communicate strategy to external stakeholders

1.501

$\begin{array}{lll}\text { Communicate direction } & 3.875 & 1.327\end{array}$

Establish and communicate business position $\quad 3.822 \quad 1.300$

Review business strategy $\quad 4.212 \quad 1.326$

$\begin{array}{lll}\text { Challenge assumptions in strategy } & 4.405 & 1.299\end{array}$

Check that business strategy is being $\quad 4.284 \quad 1.313$

implemented

Manage strategy implementation $\quad 4.383 \quad 1.243$

Plan strategic actions of the business $\quad 4.390 \quad 1.309$

CSR

$0.649 \quad 0.928 \quad 0.91$

In comparison with the industry average, how would you rate the performance of your company over the last two years in terms of the following indicators?

Supporting employees who acquire additional $\quad 4.167 \quad 1.213$

education

Deploying flexible company policies to enable $\quad 3.822 \quad 1.315$

employees to better coordinate work and

personal life

Giving adequate contributions to charities $\quad 3.621 \quad 1.360$

Using a program that is in place to reduce the $\quad 4.011 \quad 1.277$

amount of energy and materials wasted in our

business

Encouraging partnerships with local businesses $\quad 3.708 \quad 1.396$

and schools to benefit the society

Improving sustainability through our product $\quad 3.856 \quad 1.349$

designs

Improving sustainability via our product return $\quad 3.845 \quad 1.286$

policies/processes

Risk-taking (developed and validated for use in this

study)

$0.541 \quad 0.875$

0.842

My company has an operating top management philosophy of

Strong emphasis on research and development, $\quad 4.379 \quad 1.261$

technological leadership and innovations

Strong proclivity to high-risk, high-return $\quad 3.477 \quad 1.322$

investments

Growth strategy primarily through external $\quad 3.288 \quad 1.480$

financing (borrowings, capital issues, etc.)

Very competitive, "undo-the-competitors" $\quad 3.235 \quad 1.413$

philosophy

Mobilizing tangible resources to achieve goals $\quad 4.201 \quad 1.097$

Mobilizing intangible resources to pursue goals $\quad 4.053 \quad 1.198$

Table A1.

Note(s): This table summarizes the responses for each of our latent survey constructs. Average variance Summary statistics of survey items
Source(s): (Adapted from Kaplan and Norton 1996; Maignan and Ferrell 2000) 


\begin{tabular}{|c|c|c|c|}
\hline \multicolumn{2}{|l|}{ Variables } & Definitions & \multirow[b]{3}{*}{37} \\
\hline ROA & $=$ & Two-year average of return on assets (Aida-Bureau van Dijk) & \\
\hline ROS & $=$ & Two-year average of return on sales (Aida-Bureau van Dijk) & \\
\hline CSR & $=$ & The average of the ratings on seven items related to CSR activities (survey) & \\
\hline CSR_EXT & $=$ & The average of the ratings on five items related to external CSR activities (survey) & \\
\hline CSR_INT & $=$ & The average of the ratings on two items related to internal CSR activities (survey) & \\
\hline RISK $\bar{~}$ & $=$ & $\begin{array}{l}\text { Dummy variable equal to } 1 \text { if the factor score from a PCA of six items associated with } \\
\text { risk-taking activities is greater than the sample median; } 0 \text { otherwise (survey) }\end{array}$ & \\
\hline ALIGN & $=$ & $\begin{array}{l}\text { Dummy variable equal to } 1 \text { if CSR_EXT }>\text { CSR_INT and RISK }=1 \text { or } \\
\text { CSR_EXT }<\text { CSR_INT and RISK }=0 ; 0 \text { otherwise }\end{array}$ & \\
\hline REASON_COM & $=$ & $\begin{array}{l}\text { Factor score from a PCA of nine items associated with the purpose of PMS relating to } \\
\text { the communication of strategic initiatives (survev) }\end{array}$ & \\
\hline REASON_REV & $=$ & $\begin{array}{l}\text { Factor score from a PCA of nine items associated with the purpose of PMS relating to } \\
\text { the review of strategic initiatives (survey) }\end{array}$ & \\
\hline MATURITY & $=$ & $\begin{array}{l}\text { The response to a survey question capturing the length of time PMS have been in use, } \\
\text { based on a seven-point Likert-type scale (survey) }\end{array}$ & \\
\hline MULTI & $=$ & $\begin{array}{l}\text { Dummy variable equal to } 1 \text { if the firm is part of a multinational entity; } 0 \text { otherwise } \\
\text { (survey) }\end{array}$ & \\
\hline EMPLOYEE & $=$ & $\begin{array}{l}\text { The response to a survey question capturing the number of employees employed, } \\
\text { based on a seven-point Likert-type scale (survev) }\end{array}$ & \\
\hline IPIPR & $=$ & $\begin{array}{l}\text { Two-year average of industrial patents and intellectual property rights scaled by total } \\
\text { assets (Aida-Bureau van Dijk) }\end{array}$ & \\
\hline $\mathrm{PM}$ & $=$ & $\begin{array}{l}\text { Two-year average of plant and machinery scaled by total assets (Aida-Bureau van } \\
\text { Dijk) }\end{array}$ & \\
\hline ICE & $=$ & $\begin{array}{l}\text { Two-year average of industrial and commercial equipment scaled by total assets } \\
\text { (Aida-Bureau van Dijk) }\end{array}$ & \\
\hline SIZE & $=$ & Natural log of the two-year average of total assets (Aida-Bureau van Dijk) & \\
\hline LEV & $=$ & Two-year average of total debts scaled by total assets (Aida-Bureau van Dijk) & \\
\hline ACTVOL & $=$ & Standard deviation of ROA over the past five years (Aida-Bureau van Dijk) & ral \\
\hline INDUSTRY & $=$ & Dummy variable equal to 1 if the firm is in the manufacturing industry; 0 otherwise & Variable definitions \\
\hline
\end{tabular}

\section{Corresponding author}

Lorenzo Lucianetti can be contacted at: lorenzo.lucianetti@unich.it

For instructions on how to order reprints of this article, please visit our website: 